\title{
Corrigendum
}

Genome Research 25: 1135-1146 (2015)

Corrigendum: Retrotransposition creates sloping shores: a graded influence of hypomethylated CpG islands on flanking CpG sites

Fiorella C. Grandi, James M. Rosser, Simon J. Newkirk, Jun Yin, Xiaoling Jiang, Zhuo Xing, Leanne Whitmore, Sanum Bashir, Zoltán Ivics, Zsuzsanna Izsvák, Ping Ye, Y. Eugene Yu, and Wenfeng An

The authors would like to correct the inadvertent omission of a funding source in the Acknowledgments section of the initial publication of this article. The corrected text is as follows and has been updated online:

"Zsuzsanna Izsvák was funded by European Research Council-2011-ADG-TRANSPOSOstress - 294742."

doi: $10.1101 /$ gr.261677.120 


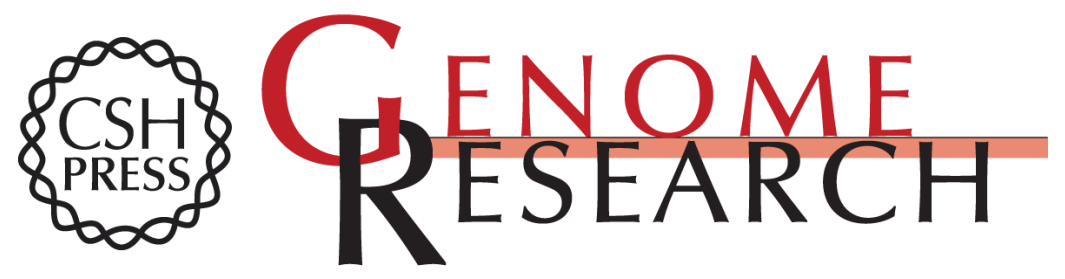

\section{Corrigendum: Retrotransposition creates sloping shores: a graded influence of hypomethylated CpG islands on flanking CpG sites}

Fiorella C. Grandi, James M. Rosser, Simon J. Newkirk, et al.

Genome Res. 2020 30: 313

Access the most recent version at doi:10.1101/gr.261677.120

Related Content Retrotransposition creates sloping shores: a graded influence of hypomethylated $\mathrm{CpG}$ islands on flanking $\mathrm{CpG}$ sites

Fiorella C. Grandi, James M. Rosser, Simon J. Newkirk, et al.

Genome Res. August , 2015 25: 1135-1146

Open Access Freely available online through the Genome Research Open Access option.

License

Email Alerting Receive free email alerts when new articles cite this article - sign up in the box at the Service top right corner of the article or click here.

\section{Affordable, Accurate Sequencing.}

To subscribe to Genome Research go to:

https://genome.cshlp.org/subscriptions 